\title{
Retextualizar no celular: implicações das tarefas de textualização e hipertextualização
}

\author{
Marina Martins Pinchemel Amorim* \\ Márcia Helena de Melo Pereira**
}

\section{Resumo}

Este artigo trata da retextualização que, segundo Marcuschi (2010), é o processo de construção de um texto a partir de um ou mais texto(s)-base. Considerando a necessidade de inserção de gêneros do discurso digitais nas aulas de Língua Portuguesa, como propõe a BNCC (BRASIL, 2018), comparou-se duas retextualizações, sendo uma produzida em papel e outra no celular, tendo o objetivo de analisar a textualização e a hipertextualização, que são consideradas tarefas de retextualização. Para tanto, foram analisados dados processuais de uma dupla de estudantes do Ensino Médio, que produziu, conjuntamente, uma carta e uma publicação de Instagram. Este trabalho apoia-se em autores como Bakhtin (2011), Costa Val (2004), Dell'Isola (2007), Koch e Elias (2008) e Xavier (2010). Com as análises realizadas, percebeu-se que textualização e hipertextualização diferenciam-se devido às possibilidades abarcadas pelo hipertexto, de caráter multissemiótico, que possibilita leitura sinestésica, independência leitora, produção multimodal, mas, como desvantagem, a cópia-colagem.

Palavras-chave: Escrita conjunta; Escrita digital; Hipertexto; Instagram; Retextualização.

\section{Introduç̧ão}

O crescente desenvolvimento das tecnologias digitais tem conduzido a sociedade a mudanças no comportamento e, consequentemente, na cultura, inaugurando a chamada cultura digital, ou cibercultura. Segundo Lèvy (1999, p. 17), a cibercultura é "o conjunto de técnicas (materiais e intelectuais), de práticas, de atitudes, de modos de pensamento e de

\footnotetext{
Mestra e doutoranda pelo Programa de Pós-Graduação em Linguística, da Universidade Estadual do Sudoeste da Bahia campus Vitória da Conquista. É licenciada em Letras Vernáculas pela mesma universidade e atua como professora do Ensino Médio pela Secretaria de Educação do estado da Bahia. E-mail: marinapinchemel@gmail.com

** É doutora em Linguística Aplicada pela Universidade Estadual de Campinas, onde também realizou o curso de mestrado em Linguística Aplicada. Atualmente, é professora adjunta do Departamento de Estudos Linguísticos e Literários da Universidade Estadual do Sudoeste da Bahia e docente do quadro permanente do Programa de Pós-Graduação em Linguística (PPGLin-UESB), campus de Vitória da Conquista, atuando na área de Linguística de Texto. Desenvolve, atualmente, projeto de pesquisa sobre processo de construção de textos, gênese de textos, relação entre estilo individual e estilo de gênero, crítica genética, autoria e ensino de texto. E-mail: arciahelenad@yahoo.com.br
}

Data de submissão: dez. 2020 - Data de aceite: mar. 2021 http://dx.doi.org/10.5335/rdes.v17i01.11514 
valores que se desenvolvem juntamente com o crescimento do ciberespaço". Quando Lèvy (1999) lançou este conceito, o ciberespaço era restrito à rede mundial de computadores. Atualmente, o ciberespaço comporta, entre outros suportes, também o smartphone.

Concomitante ao avanço tecnológico, uma nova forma de enunciar eclodiu, à qual Nelson (1990) denominou de "hipertexto". Assumimos o conceito de hipertexto de acordo com Xavier (2010, p. 208), para quem hipertexto é "uma forma híbrida, dinâmica e flexível de linguagem que dialoga com outras interfaces semióticas, adiciona e acondiciona à sua superfície formas outras de textualidade". Esse modo de produção textual, segundo Marcuschi (2010), não é um gênero discursivo, mas pode estender-se a diversos gêneros, dando a eles características específicas. Nas últimas duas décadas, alguns gêneros discursivos vêm emergindo necessariamente no meio digital, como o blog, a publicação de Facebook, o tweet e a postagem de Instagram. Gradativamente, esses gêneros, assim como as redes sociais que os abarcam, tornam-se parte do cotidiano de diversos jovens, por meio da - parcial - popularização da internet.

É papel da escola e, mais especificamente, dos docentes da área de Língua Portuguesa, oportunizar o contato dos alunos com diversos gêneros discursivos, para que se comuniquem em sociedade de maneira eficaz. As mudanças nas formas de enunciar, devido à interação na internet, não devem ser alheias à escola, assim como orientado em documentos norteadores da educação brasileira, a exemplo da Base Nacional Comum Curricular (BNCC), publicada em 2018, que incentiva a incorporação de recursos digitais no ensino-aprendizagem, tendo em vista instrumentalizar o estudante para se comunicar por meios dos gêneros discursivos digitais.

Quando se refere às práticas de leitura e produção textual, a retextualização é uma ferramenta eficaz nas atividades escolares. Este é um processo no qual um novo texto é produzido tendo em vista texto(s) anterior(es). Segundo Marcuschi (2010), a retextualização pode envolver tanto textos orais quanto escritos e é comum no cotidiano. Dell'Isola (2007) define sete tarefas de produção da retextualização: leitura, compreensão, identificação do gênero, retextualização, conferência, identificação do novo texto e reescrita. Enquanto prática metodológica no ambiente escolar, a retextualização apresenta grandes contribuições, como o exercício da compreensão, estímulo da criticidade e uso social da linguagem por meio de gêneros.

Posto isso, o presente estudo surgiu da necessidade de incorporar, na escola, leitura e escrita em ambientes virtuais e objetiva analisar as tarefas de textualização e hipertextualização em processos 
de retextualização. Para tanto, partiremos das retextualizações feitas em suporte físico (papel) e em suporte digital (smartphone), considerando as definições de suporte de Marcuschi (2008), as quais originaram uma carta e uma publicação de Instagram. Estas foram produzidas conjuntamente por uma dupla de estudantes do Ensino Médio da rede estadual da Bahia, com a temática da valorização da vida, com o intuito de diferenciá-las. A metodologia utilizada foi a comparação entre dados processuais, obtidos por meio de transcrições das gravações audiovisuais captadas enquanto a dupla retextualizava, além de uma entrevista realizada posteriormente.

Este artigo é organizado em seções, a seguir dispostas: primeiramente, discutimos nossa fundamentação teórica, por meio de autores e conceitos que corroboram com nossa investigação, tais como: Bakhtin (2011); Xavier (2010); Marcuschi (2010); Dell'Isola (2007); Matencio (2002); Costa Val (2004). Em seguida, traçamos o percurso metodológico de coleta de dados e, logo após, é apresentada a análise propriamente dita, que consiste na descrição das atividades de textualização e hipertextualização nas retextualizações. Por último, na seção de considerações finais, retomamos nosso objetivo e os resultados obtidos.

\section{A escola em meio aos gêneros do discurso e à ascensão do hipertexto}

A teoria dos gêneros do discurso, postulada por Bakhtin (2011), tem sido base para muitos estudos linguísticos que se dedicam a investigar os usos sociais da linguagem. $\mathrm{Na}$ educação, o trabalho com os gêneros deve nortear a abordagem para o ensino de línguas. Essa orientação parte do caráter dos gêneros, uma vez que estão relacionados ao funcionamento da língua em práticas sociocomunicativas, reais e concretas, produzidas por sujeitos que interagem nas esferas das relações humanas e da comunicação. Nesta seção, traçaremos um breve panorama da teoria dos gêneros do discurso, segundo o filósofo russo, Mikhail Bakhtin e, em seguida, enfocaremos nos estudos dos gêneros emergentes na era digital, consoante Xavier (2010) e Marcuschi (2010).

A materialização da língua, segundo Bakhtin (2011), dá-se por meio de enunciados, orais ou escritos. Um enunciado não é uma forma rígida e estagnada, uma vez que se realiza no ato da enunciação e é dinâmico. No entanto, apesar da individualidade dos enunciados, os campos da atividade humana elaboram seus tipos relativamente estáveis de enunciados, os quais Bakhtin (2011) denomina "gêneros do discurso". Isto posto, 
sempre que enunciamos, atuamos por meio de gêneros, que são alicerçados sob três pilares: conteúdo temático, forma composicional e estilo.

Uma vez que os enunciados não são estanques e os campos de atividade humana, inúmeros, é impossível listar todos os gêneros do discurso existentes, já que a todo tempo surgem novos, devido às relações socioculturais das sociedades. A era digital que vivenciamos influencia nesse processo, de forma que é possível identificar gêneros fundamentalmente digitais, que funcionam com hipertextos.

A BNCC revela congruência com a perspectiva bakhtiniana dos gêneros do discurso, ao orientar, na área de Língua Portuguesa, o trabalho com gêneros para nortear o "desenvolvimento das capacidades de leitura, produção e tratamento das linguagens" (BRASIL, 2018, p. 67) para possibilitar, ao estudante, a atuação em diversas esferas sociais. Além disso, a BNCC (BRASIL, 2018) reconhece que, com o avanço da tecnologia digital, os jovens, em sua maioria, são ativos nas interações propiciadas por esse meio, engajando-se nas formas de interação multimodais. Posto isso, há a necessidade de que o estudante conheça gêneros discursivos digitais e aproprie-se deles para a comunicação efetiva, considerando as atualizações sociais.

A multimodalidade ou multissemiose é uma característica elementar do hipertexto, que teve sua ascensão a partir do surgimento da cibercultura. Xavier (2010) define o hipertexto a partir de características como hibridismo, dinamicidade, flexibilidade, diálogo com várias linguagens e interfaces. Os hipertextos são capazes de convergir diversos recursos semióticos, como da modalidade verbal (oral e escrito), modalidade sonora (músicas, sons, etc) e modalidade visual (imagens, fotos, ilustrações, vídeos, animações, etc), como posto por Rojo e Barbosa (2015). Essa mescla de linguagens é o que atribuiu ao hipertexto seu caráter multissemiótico. Por conseguinte, novas formas de leitura e escrita são suscitadas.

Uma vez que o leitor de hipertexto tem contato com múltiplas linguagens simultaneamente, em uma atividade multissensorial, a leitura é sinestésica, como nomeia Xavier (2010), o usuário é capaz de demonstrar, de forma mais ativa, a interação com o texto, sendo estimulado a participar da construção de sentidos do hipertexto. O usuário da web tem maior autonomia para traçar seus percursos de leitura e, em muitas plataformas, é capaz de acrescentar ou comentar informações sobre o hipertexto lido. Além disso, ao acionar diversas linguagens, a compreensão pode ser ampliada. Esta particularidade demonstra uma vantagem de adotar gêneros discursivos que circulam em meios digitais em atividades de ensino-aprendizagem, uma vez que podem ser mais envolventes do que outras mais canônicas. 
Assim como a leitura, a escrita de hipertexto é também diferenciada, a começar pelas ferramentas utilizadas para esse fim. A depender do suporte em que o usuário utilizará para produzi-lo (computador, notebook, tablet, smartphone), as ferramentas se alteram. Neste trabalho, focamos no uso do smartphone e temos, nesse único suporte, as ferramentas que o estudante precisará utilizar para produzir o hipertexto. Por meio do smartphone, é possível capturar fotografias e vídeos, combinar ilustrações, escrever, gravar áudios, pesquisar diversos outros hipertextos, entre demais atividades. Esses comandos podem ser feitos por meio de voz ou, mais usualmente, com um click de comando ou com a utilização do teclado. Demais especificidades que correspondem à hipertextualização serão desenvolvidas ao longo da análise exposta neste artigo. A respeito de textualização e hipertextualização, discorreremos na seção seguinte.

\section{A retextualização como ferramenta para o trabalho voltado à produção textual}

A retextualização é uma atividade de transformação de um (ou mais) texto(s) para a criação de um novo. Essa transformação incide em mudanças de ordem textual, linguística e discursiva, devido à mudança de propósito (MATENCIO,
2002). É possível perceber a retextualização nos mais diversos campos da atividade humana, uma vez que ocorre tanto em textos orais quanto em escritos. No cotidiano, ao receber uma mensagem via Whatsapp, de maneira escrita, e contar a alguém sobre o que foi lido, temos uma forma de retextualização. $\mathrm{Ou}$, ainda, ao ler um anúncio no jornal e anotar suas principais informações, estamos retextualizando. Para retextualizar, é mister que o usuário da língua compreenda o(s) texto(s)-base, portanto, esta é uma atividade que, em contexto educativo, apresenta muitas contribuições para a aprendizagem. No campo escolar, podemos exemplificá-la com a produção de uma resenha sobre determinada obra (livro, filme, álbum musical etc.) e na exposição oral de um artigo científico.

Segundo Marcuschi (2010), existem quatro possibilidades de retextualização: (i) fala-fala; (ii) fala-escrita; (iii) escrita-escrita; (iv) escrita-fala. Os tipos elencados por Marcuschi (2010) elucidam as alternativas de retextualização dessa atividade, o que a torna eficaz como proposta metodológica para o ensino, por exemplo, de línguas. Dell'Isola (2007) descreve, a partir de uma pesquisa realizada com a retextualização escrita-escrita com alunos do Ensino Fundamental, sete tarefas de produção para retextualizar. A primeira é a leitura dos textos-base, seguida da compreensão textual, que envolve tanto os textos-base como 
também o próprio texto a ser desenvolvido. A terceira tarefa é a identificação do gênero, que se refere à percepção das características do gênero do texto-base. A retextualização é a quarta tarefa e, segundo a autora, é a escrita do novo texto, produto da retextualização (Dell'Isola, 2007). Em seguida, há a conferência, relativa à revisão do texto, na qual o escrevente deve certificar-se de que 0 conteúdo do novo texto produzido é similar ao do texto-base. A identificação do novo texto é a sexta tarefa de produção, referente à análise das características do gênero do novo texto produzido. Por último, a reescrita, que é concernente aos ajustes no próprio texto, seja textuais, linguísticos ou discursivos. Embora as tarefas de produção sejam enumeradas, é válido salientar que não ocorrem de forma linear e ordenada, podendo variar em cada processo de retextualização. Dedicamo-nos, neste artigo, à quarta tarefa, a qual Dell'Isola (2007) denominou "retextualização", mas optamos por nomeá-la como textualização (no caso de textos em suportes físicos) e hipertextualização (para hipertextos), uma vez que consideramos que a retextualização corresponde ao todo do processo. Diante de nosso objetivo, faz-se necessário descrever, brevemente, em que consistem textualização e hipertextualização.

A textualização é um processo atrelado à textualidade e inerente à retextualização, da mesma forma que em qualquer produção textual. Conforme Costa Val (2004), textualidade foi um termo criado, em 1981, por Beaugrande e Dressler, para indicar o modo de processamento textual que torna uma sequência linguística em um texto propriamente dito. Para tanto, são elencados sete fatores que orientam esse processo: coerência, coesão, situacionalidade, informatividade, intertextualidade, intencionalidade e aceitabilidade. Os padrões funcionam integrados a três princípios reguladores: eficiência, eficácia e adequação. A eficiência, segundo Beaugrande e Dressler (1981), tem ligação com o pouco esforço que deve existir para a comunicação entre os interlocutores. Já a eficácia é relativa às condições que o texto consegue criar para que o escrevente/falante alcance seu objetivo com a comunicação. Por fim, a adequação tem relações com o contexto, uma vez que um texto se mostra pertinente e relevante a depender da situação comunicativa.

De acordo com Costa Val (2004, p. 03), a textualidade é

[...] um princípio geral que faz parte do conhecimento textual dos falantes e que os leva a aplicar a todas as produções lingüísticas que falam, escrevem, ouvem ou lêem um conjunto de fatores capazes de textualizar essas produções. Explicando melhor: não vamos entender a textualidade como algo que está nos textos, mas como um componente do saber lingüístico das pessoas.

Ou seja, a textualidade não reside no texto, mas, nos leitores, ouvintes, 
falantes e escreventes, quase que de maneira internalizada, como princípio geral da língua. Como destaca a autora, "cada texto pode ser textualizado de maneiras diferentes por diferentes ouvintes ou leitores" (COSTA VAL, 2004, p. 03) e textualizar é tornar uma sequência linguística em um texto, lugar de interação.

A textualização, por sua vez, corresponde às ações de mobilização dos saberes de textualidade para constituição de sentidos sob uma sequência linguística. Portanto, a textualização é um processo no qual operações são realizadas pelo escrevente/falante tendo em vista a textualidade: "No processo de textualização, um mesmo texto pode ser considerado incompreensível e impróprio por determinados interlocutores, em determinada situação, e ser considerado plenamente inteligível e adequado por outros interlocutores, noutra situação" (COSTA VAL, 2004, p. 19). Diante do exposto, em situações diferentes, um mesmo texto pode ser considerado mais ou menos coerente, muito informativo ou pouco informativo, coeso ou não coeso, etc.

A hipertextualização, também viés de nossa análise neste estudo, é similar à textualização, no sentido de corresponder às operações que o usuário realiza, mas, nesse caso, no processo de concepção de um hipertexto, considerando as ferramentas, as leituras e o hipertexto produto da retextualização. As características do hipertexto, anteriormente discutidas (hibridismo, dinamicidade, flexibilidade, multissemiose), indicam a necessidade de investigar as operações de produção que ocorrem nesse tipo de retextualização em comparação à retextualização que resulta em um texto não multimodal, portanto, nossa análise demonstrará as diferenças e semelhanças entre os dois processos.

Finalizadas nossas considerações teóricas, apresentaremos, em seguida, a metodologia empregada neste trabalho.

\section{Percurso metodológico}

A metodologia adotada para a realização deste estudo caracteriza-se como qualitativa e descritiva, posto que detalhamos os dois processos de retextualização analisados, tendo em vista alcançar o objetivo proposto. Os dados utilizados foram coletados em 2019, durante uma pesquisa de mestrado em Linguística em andamento, cadastrada no Certificado de Apresentação para Apreciação Ética (CAAE) sob o número 17428619.9.0000.005.

Os sujeitos pesquisados foram duas alunas que cursavam a $2^{\mathrm{a}}$ série do Ensino Médio de um colégio estadual da Bahia, em uma turma na qual a pesquisadora estava inserida como professora. Ambas, aqui denominadas $\mathrm{E}$ e $\mathrm{F}$, tinham 16 anos de idade e foram selecionadas devido à afinidade com a disciplina de Língua Portuguesa e pela amizade que demons- 
travam, uma vez que, em outros estudos processuais, como em Pereira (2005), a afinidade entre a dupla foi um fator essencial para obtenção dos dados, já que são, majoritariamente, frutos do diálogo durante a produção textual e a entrevista. A coleta dos dados se deu pela aplicação da seguinte Sequência Didática (SD):

Figura 1 - Sequência didática aplicada aos sujeitos da pesquisa

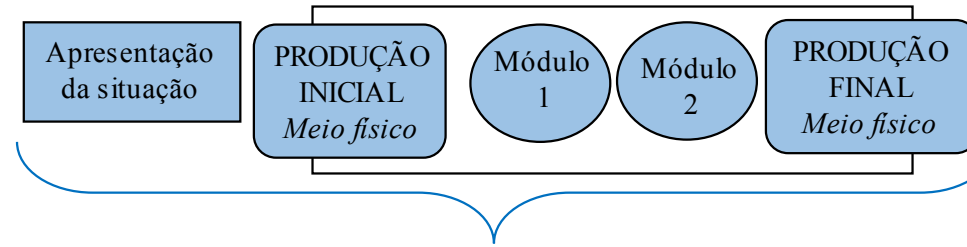

Processo 1

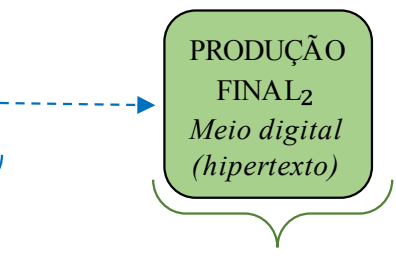

Processo 2

Fonte: Elaborado pelas pesquisadoras

A SD apresentada foi elaborada de acordo com os pressupostos de Dolz, Noverraz e Schneuwly (2011), inclui dois processos de produção de gêneros, e foi aplicada em toda a turma na qual a dupla pesquisada estava inserida, ainda que analisamos os dados relativo à dupla E e F. O primeiro processo refere-se à produção de uma carta em papel (suporte físico). A apresentação da situação foi feita por meio da leitura de livros literários. Em seguida, a produção inicial constituiu-se da escrita de uma carta pessoal sobre a obra lida, para um dos destinatários sugeridos, à escolha dos estudantes: 1- uma personagem do livro; 2- autor do livro; 3- colega de sala. Esta produção serviu como avaliação diagnóstica, por meio da qual foi possível eleger os temas a serem trabalhados nos módulos 1 e 2 : a estrutura do gênero carta pessoal e questões gramaticais, respectivamente. A produção final foi a escrita de uma nova carta, em dupla. Esta teve a temática da valorização da vida, em congruência com a campanha anual do "Setembro Amarelo", que visa a conscientização sobre a depressão e o suicídio. Para esta atividade, as duplas de alunos dispuseram de textos-base discutidos em sala de aula: (i) postagem de Instagram sobre Setembro Amarelo; (ii) reportagem televisiva "Morte de Robin Williams levanta discussão sobre depressão no humor”; (iii) a mensagem motivacional "Depression - in memory of Robin Williams"; (iv) a reportagem do site G1 "Setembro Amarelo: como conversar com alguém que está pensando em cometer suicídio". Assim, as duplas deveriam escrever uma carta a alguém que estivesse em um momento de fragilidade emocional, dirigindo-se a 
essa pessoa com palavras de conforto e motivação. As cartas seriam colocadas em um mural, na área de convivência da escola, e poderiam ser lidas por qualquer pessoa da comunidade escolar. Portanto, as duplas não saberiam os destinatários dos textos. No momento de elaboração das cartas, a dupla analisada, E e F, dirigiu-se a uma sala reservada, com equipamentos de gravação, para registro do processo.

O segundo processo foi realizado uma semana após o primeiro e refere-se à produção de uma publicação de Instagram por meio do smartphone (suporte digital). Apenas a dupla pesquisada realizou esse procedimento, no qual deveria produzir uma publicação no perfil do Instagram da turma com a mesma temática da carta. Durante o processo, E e F optaram por produzir três publicações de Instagram. No entanto, devido às limitações de espaço de um artigo, optamos por analisar somente uma.

Durante as duas retextualizações, as atividades da dupla foram registradas em áudio e vídeo, para acessarmos as conversas que mantiveram durante as produções e, assim, percebermos quais operações realizaram, bem como demais peculiaridades envolvidas nas retextualizações. Uma semana após as produções, a dupla foi convidada para uma entrevista semiestruturada, registrada em áudio, na qual responderam sobre aspectos observados pela pesquisadora na retextualização. As três gravações foram transcritas, utilizando o programa de computador Word. Assim, os dados angariados dos quais nos valemos para este artigo são: (a) rascunho da carta; (b) versão final da carta; (c) publicação de Instagram; (d) transcrições dos diálogos durante as retextualizações e da entrevista.

A publicação supracitada foi constituída por três imagens escolhidas pelas alunas e de uma legenda, que serão analisadas mais à frente. Além dos materiais já elencados, fazem parte do corpus da pesquisa os textos-base utilizados pela dupla para retextualizar: a reportagem do G1 sobre Setembro Amarelo (2019) e um texto de instrução sobre o gênero carta pessoal, produzido pela professora/ pesquisadora.

Explicitado o percurso metodológico adotado na pesquisa realizada, a seção seguinte discutirá os dados coletados, tendo em vista as tarefas de textualização e a hipertextualização.

\section{Operações de textualização e hipertextualização envolvidas nas retextualizações}

Como anteriormente exposto, nosso objetivo é analisar a quarta tarefa de produção da retextualização que, no caso do texto em suporte físico, denominamos como textualização e, no hipertexto, 
em suporte digital, denominamos como hipertextualização. Dessa forma, nossa análise apresentará dados ilustrativos com as principais características desses processos, iniciando pela investigação da retextualização da carta e, em seguida, da publicação de Instagram.

A Figura 2, a seguir, apresenta um recorte da carta, a nível de ilustração.

Figura 2 - Recorte da carta produzida pela dupla

4 de vitulro vole 2019

dá paro edeara

como voe ustá? Puredremes ave as cosas mä́s utāe inde miste lem, vimos uque ustá upassando por um mponentie muito dilicil. Espera. mos aue por meic desta earta possamis the afridar de alguma

Fonte: Banco de dados das pesquisadoras

O recorte acima é correspondente ao início do texto-produto da retextualização, no qual temos: local, data, saudação e introdução. Devido às questões de espaço disponíveis em um artigo, serão estas as partes da carta que analisaremos.

As seis primeiras falas do diálogo da dupla E e F, na retextualização da carta, estão dispostas abaixo:

\section{$\mathrm{E}:$ Tem que colocar isso aqui \\ F: Tem que colocar isso primeiro \\ E: É, mas não dá pra colocar São Paulo, tem que colocar $\mathrm{M}$}

F: M. M... Hoje é que dia?
E: Dia 4 de outubro

F: 2019. Pronto. Ai primeiro é a saudação. Cê vai colocar como? Porque tipo, ela falou pra gente fazer tipo pra uma amiga

E: É, coloca assim...

F: Olá, tudo bem?

E: Não. Tem que colocar tipo assim "Olá, cara amiguinha", ou "Olá, caro colega".

F: É, pode ser. Olá, caro colega [escrevendo]

Conforme disposto acima, as alunas iniciaram a retextualização a partir da identificação de características do gênero em questão, dispostas em um texto-base impresso, que consistia em instruções acerca do gênero carta pessoal, pelas quais puderam verificar que a carta deve iniciar com a escrita do local e data dos remetentes. Assim, começaram a textualizar na folha de rascunho do texto. Primeiro, colocaram o nome da cidade (que abreviamos para M) e a data, "4 de outubro de 2019". Para textualizar essas informações no papel propriamente dito, elas, inicialmente, fizeram uma textualização oral, tendo em vista socializar entre si as informações que pretendiam colocar. Uma vez que se tratava de uma escrita conjunta, essas decisões deveriam ser acordadas entre as duas alunas, portanto, falar antes de escrever foi um aspecto recorrente neste processo. Em seguida, E e F constataram que 
deveriam produzir a saudação da carta, também devido à leitura do texto-base. A estudante F sugeriu “Olá, tudo bem?", enquanto E propôs "Olá, cara amiguinha" e "Olá, caro colega". A dupla optou pela última sugestão e, então, a aluna $\mathrm{F}$ escreveu: Olá, caro colega" para saudar o leitor da carta. É necessário salientar que, pela proposta de produção da carta, as alunas não saberiam, ao certo, quem leria o texto.

A seguir, apresentamos um quadro no qual comparamos o primeiro trecho da carta disposta no texto-base ao da carta produzida pela dupla. Na primeira coluna do Quadro 1, à esquerda, está a carta exposta no texto-base e, à direita, a introdução da carta das alunas:

\section{Quadro 1 - Parte da carta do texto-base e da carta da dupla}

\begin{tabular}{|c|c|}
\hline Carta do texto-base & $\begin{array}{c}\text { Carta produzida pela } \\
\text { dupla }\end{array}$ \\
\hline $\begin{array}{l}\text { São Paulo, } 24 \text { de no- } \\
\text { vembro de } 2019 .\end{array}$ & $\begin{array}{l}\text { M, 4 de outubro de } \\
2019\end{array}$ \\
\hline Olá, prima Carmen! & Olá, caro colega! \\
\hline $\begin{array}{l}\text { Como vão todos por } \\
\text { aí? Espero que bem. } \\
\text { Por aqui estamos } \\
\text { bem e as coisas vão } \\
\text { andando! Estou Ihe } \\
\text { escrevendo para sa- } \\
\text { ber onde você vai } \\
\text { passar o Natal neste } \\
\text { ano. }\end{array}$ & $\begin{array}{l}\text { Como você está? Per- } \\
\text { cebi que as coisas não } \\
\text { estão indo muito bem. } \\
\text { Vi que está passando } \\
\text { por um momento muito } \\
\text { difícil. Esperamos que } \\
\text { por meio dessa carta } \\
\text { possamos te ajudar de } \\
\text { alguma forma. }\end{array}$ \\
\hline
\end{tabular}

Fonte: Elaborado pelas pesquisadoras.
Na contraposição entre as duas cartas é possível visualizar as semelhanças no que diz respeito às primeiras informações inseridas em local, data e saudação. Todavia, as alunas não realizaram uma cópia mecânica, pois adequaram os dados à realidade delas: colocaram o nome da cidade em que estavam, inseriram a data real e saudaram um colega de forma genérica - visto que a carta não tinha um destinatário definido. Além dessas, algumas peculiaridades podem também ser identificadas em cada parágrafo introdutório das cartas, que discutiremos a seguir.

No texto-base, temos a pergunta: "Como vão todos por aí?" e, na retextualização: "Como você está?", revelando as similaridades entre os textos, o que indica como o texto-base instrucional sobre o gênero foi relevante para a textualização das alunas. Até escreverem todo o parágrafo de introdução, muitas discussões permearam as escolhas da dupla. Discutiremos algumas dessas situações.

$\mathrm{Na}$ proposta inicial da retextualização, o texto instrucional sobre o gênero carta pessoal não era um material previsto com texto-base, uma vez que foi utilizado somente durante o módulo 1 da $\mathrm{SD}$, para orientar os alunos acerca das características do gênero. No entanto, este tornou-se um texto-base, dada a utilização da dupla durante a retextualização, elucidando uma latente preocupação 
da dupla com a estrutura do gênero, que, de acordo com Bakhtin (2011), é um dos pilares dos gêneros do discurso.

Durante a entrevista realizada com as alunas, elas foram questionadas sobre a recorrente consulta a este material, para verificar a estrutura da carta. Quando perguntadas sobre já terem escrito uma carta, as duas alunas responderam negativamente e F complementou: "É mais aquelas cartinhas que assim não tem estrutura [...] Você pega um pedacinho de coisa e coloca: 'ah, não sei o que', pro coleguinha". Nas palavras de E, seria um "bilhete", nomeado por F como "cartinha": "É, não é uma carta comum, que a gente falava "cartinha". Portanto, as alunas revelaram que aquela foi a primeira carta que escreveram, o que justificava a necessidade de recorrer a um material que indicasse seus principais aspectos. Elas declararam já terem produzido um outro gênero, que chamaram de "cartinha”. Devido às características apontadas por elas sobre esse gênero - frases soltas, sem data, sem estrutura fixa - a professora perguntou se era similar a um bilhete e as alunas concordaram.

Segundo Koch e Elias (2008), há uma competência denominada "metagenérica" em todos os indivíduos, fazendo-os capazes de produzir e compreender gêneros discursivos mesmo sem o domínio completo, de maneira que orienta as práticas sociocomunicativas e até a denominação dos gêneros. As alunas E e F conseguiram constatar que a experiência que tiveram, no passado, não era escrevendo cartas da mesma forma que escreveram no momento da pesquisa, por isso, utilizaram o nome "cartinha", diferenciando-as. A competência metagenérica viabilizou a interação das alunas com os gêneros do discurso abordados e sustentou a construção dos sentidos, atuando até mesmo na denominação do gênero "cartinha".

Em outra situação na produção da introdução da carta, temos o seguinte diálogo:

E: Coloca isso, então.

F: Mas esse "E ai" não tá batendo. Tem que trocar, porque se tipo coloca assim "E aí, como está aí?", não tá batendo. "E ai", "e ai"?

E: Mas já tem "olá", então não precisa colocar "E ai", pode perguntar direto: "como você está?"

F: Olá, caro colega. Como você está? [escreve] "Está" tem acento, não tem? Sei lá... Gente, que isso... [risos]

E: Coloca o "está" e coloca com acento. Se não fica "esta", não?

F: Esta. Verdade. "Como você está?". Percebi que por aí as coisas não vão muito bem, pois sei que está passando por um momento muito difícil.

A discussão exposta acima iniciou devido à repetição do advérbio "aî" no enunciado que iniciaria o texto, "E aí, como está aí?", que causou certo descon- 
forto à estudante F. A colega E resolveu a questão sugerindo perguntar, diretamente: "Como você está?". Assim, F escreveu o enunciado apresentado pela parceira, mas verbalizou uma dúvida acerca da acentuação da palavra "está", o que caracteriza uma revisão do texto. Após resolvida a questão ortográfica com ajuda de $\mathrm{E}$, a estudante $\mathrm{F}$ já começou a oralizar um novo enunciado para a carta. Durante a entrevista, a repetição que gerou conflito nesta textualização foi levantada pela pesquisadora. Segundo a aluna $\mathrm{F}$, a repetição fazia com que o texto não tivesse "muito nexo" porque estava "repetindo bastante". A colega completou: "Sem sentido". Segundo F, seria importante não ter repetições na carta "porque era mais uma carta formal".

De acordo com E e F, a expressão "não está batendo" referia-se à repetição de "aî", que seria inadequada uma vez que o gênero requeria certa formalidade (não sabiam quem era o leitor) e, ainda, que repetição de termos poderia causar desinteresse no leitor. Essas afirmações fazem-nos refletir a respeito da repetição nos textos orais e escritos. Antunes (2005) revela-nos que a repetição é um procedimento de construção da coesão e é composta por três recursos: paráfrase, paralelismo e repetição propriamente dita. A paráfrase é "voltar a dizer o que já foi dito antes, porém, com outras palavras, como se quiséssemos traduzir o enunciado" (ANTUNES, 2005, p. 62, grifo da autora). O paralelismo, por sua vez, é um recurso de estilo, na qual são utilizados segmentos semânticos e estruturas gramaticais similares. Por fim, a repetição propriamente dita, que ocorre nos dados descritos da dupla, é dizer algo anteriormente colocado no texto valendo-se de uma unidade que apareceu previamente. A repetição, segundo Antunes (2005), é equivocadamente concebida, de maneira geral, como um recurso da conversa coloquial e predominantemente informal. Na fala de E, durante a entrevista, isso foi exemplificado, visto que ela afirmou que utilizar a unidade "aí" mais de uma vez na carta tornaria o texto "muito repetitivo, uma coisa muito informal, de falar, de escrever".

Mais à frente no diálogo, quando as alunas terminaram o rascunho da introdução, a estudante $\mathrm{F}$ fez um comentário que revelou outra peculiaridade da textualização da carta: "É difícil fazer uma carta, sabia?", disse ela. Na entrevista com a dupla, a professora indagou a respeito das dificuldades que envolveram a retextualização da carta:

$P$ : Em um momento, F fala: "escrever carta é difícil, sabia?". Quais dificuldades vocês encontraram para escrever esse gênero?

E: É como a gente disse antes, acho que a forma de escrever. A dúvida nas palavras.

$F$ : $E$ também a gente nunca tinha escrito nenhuma carta, aí a gente ficava muito na dúvida: "ah, será que é isso mesmo? Será que tá bom?". 


\section{E: É.}

F: "E aí, tá parecendo uma carta ou não tá?"

E: "Ou tá parecendo um bilhete?"

Conforme as alunas apontaram, as dificuldades se deram por dois motivos: a linguagem mais formal e a pouca habilidade com o gênero, em razão de estarem produzindo-o pela primeira vez. Mais uma vez, por meio desses indícios, temos a manifestação da competência metagenérica inerente aos sujeitos, como discorrem Koch e Elias (2008), pois a dupla tinha noção a respeito do novo gênero que estavam apreendendo, ainda que não tivessem refletido sobre isso.

Por meio dos dados indiciários discutidos para exemplificar a tarefa de textualização no processo de retextualização que originou a carta, foi possível constatar que a textualização oral se fez presente ao longo do processo e as escolhas linguísticas foram realizadas priorizando a textualidade e considerando as especificidades do gênero e da situação de produção. Dúvidas ortográficas permearam a escrita da dupla, uma vez que assumiram uma linguagem mais formal, o que demonstrou ser uma dificuldade na atividade. Além desse aspecto, elas elegeram a estrutura da carta como outra dificuldade, uma vez que precisaram, constantemente, conferir se o texto, de fato, assemelhava-se à uma carta, já que não tinham costume de produzi-lo.
Agora, passaremos à análise da publicação de Instagram construída pela dupla, composta de três imagens escolhidas pelas estudantes e uma legenda, como podemos vislumbrar abaixo, por meio de um printscreen (captura de tela):

Figura 3 - Publicação de Instagram produzida pela dupla

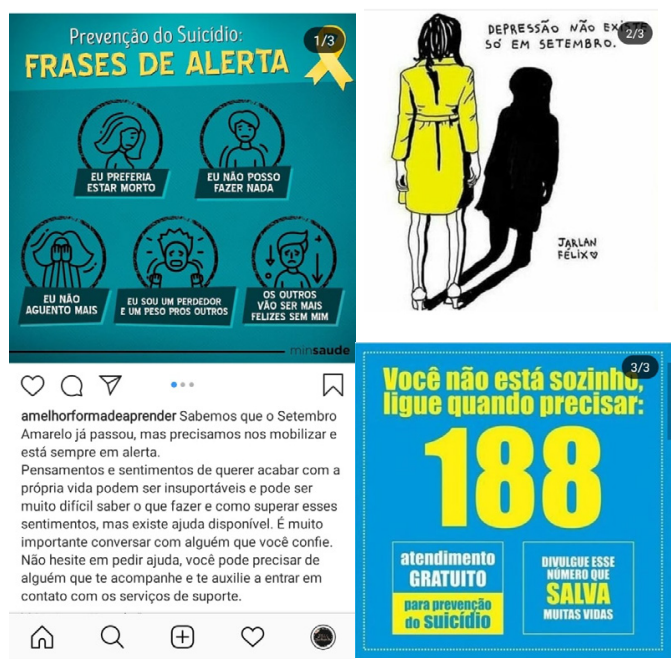

Fonte: Banco de dados das pesquisadoras.

A elaboração desta publicação deu-se em virtude de uma ideia de $\mathrm{F}$ a respeito da legenda. Ela textualizou oralmente à colega $\mathrm{E}$ sua sugestão e, por isso, partiram em busca de recursos semióticos que pudessem compor o hipertexto. As imagens foram pesquisadas em sites como Google Imagens e Pinterest, com palavras-chaves, tais quais "depressão" e "prevenção ao suicídio", como lemos na fala de E, abaixo: 
E: Tô pensando aqui. Vou no Pinterest procurar mais imagens. Prevenção... Prevenção ao suicídio. Essa aqui? Só tem setembro... Aqui: "Depressão não existe só em Setembro". Essa aqui é boa, hein? Tem uma aqui legal: sintomas do suicídio...

Para a retextualização que originou uma publicação de Instagram, a dupla não utilizou os textos-base impressos entregues pela professora, como o fizeram na produção da carta. $\mathrm{O}$ fato de estarem retextualizando no smartphone propiciou a busca própria pelos hipertextos que seriam base para a publicação. Essa situação relaciona-se ao que Xavier (2010) nomeia de "independência leitora", mais suscitada na internet do que em textos em suportes físicos, uma vez que o usuário possui uma diversidade de informações à sua disposição e pode traçar seu percurso de formação. Dessa forma, temos que os textos-base utilizados para a retextualização que originou a publicação de Instagram são majoritariamente hipertextos pesquisados pelas próprias alunas, destacando a leitura sinestésica, atividade multissensorial, em razão de ativar diversas linguagens para apreensão de significados (XAVIER, 2010).

Uma vez que as alunas estavam produzindo a segunda publicação de Instagram sobre o tema proposto e já tinham encontrado diversas imagens, a escolha das três figuras para compor a publicação foi veloz. Vejamos a discussão delas nesse momento da produção:
F: Aquela lá... Essa aqui, ó! Que aí, nessa que cê vai colocar aquele outro. Não, mas essa ordem aí tá ruim.

E: Qual?

F: Essa ordem.

E: Cê acha? É verdade. Colocar ao contrário.

F: Ó, coloca essa primeiro

E: Não, essa segunda

F: Não, essa primeiro. Essa segunda

E: Essa primeira.

F: Essa segunda e o "Ligue", o último. Pronto.

No trecho acima, E e F estavam discutindo sobre as imagens e a ordem que deveriam aparecer na publicação, revelando uma preocupação que não partiu diretamente do gênero, como na carta. Na publicação de Instagram, os usuários podem montar sua publicação colocando os recursos semióticos na ordem que desejar, enquanto na carta as alunas ficaram ancoradas à estrutura apresentada no texto-base: local e data, saudação, introdução, etc, ordenadamente, sem muita liberdade nesse aspecto. $\mathrm{O}$ processo de escolha de imagens e da ordem de apresentação na publicação pode ser considerado como parte da hipertextualização, uma vez que os recursos 
semióticos integram a publicação, assim como demais hipertextos, de forma geral.

Após resolverem as questões semióticas, as alunas partiram para a composição da legenda, a seguir transcrita:

Sabemos que o Setembro Amarelo já passou, mas precisamos nos mobilizar e está sempre em alerta. Pensamentos e sentimento de querer acabar com a própria vida podem ser insuportáveis e pode ser muito difícil saber o que fazer e como superar esses sentimentos, mas existe ajuda disponível. É muito importante conversar com alguém que você confie. Não hesite em pedir ajuda, você pode precisar de alguém que te acompanhe e te auxilie a entrar em contato com os serviços de suporte.

Durante a elaboração da legenda, uma peculiaridade da escrita digital surgiu: a cópia-colagem. Embora tenhamos citado, previamente, que a publicação surgiu devido à ideia de legenda sugerida por $\mathrm{F}$, as alunas não a acharam suficiente e copiaram boa parte da legenda de um outro hipertexto online. Assim, o enunciado criado por F "Sabemos que o Setembro Amarelo já passou, mas precisamos nos mobilizar e está sempre em alerta” é, na verdade, uma introdução para o texto que foi copiado e está sem referências.

A ação de cópia-colagem é tratada por Abranches (2016) como um problema historicamente enraizado, pois surgiu muito antes do advento da internet, com as cópias de enciclopédias que os estudantes já faziam em trabalhos escolares. De maneira geral, as fontes de pesquisa e informação mudaram, concentrando-se, muitas vezes, na internet, pela gama de conteúdos variados e praticidade de busca. Por isso, é de sites da internet que muitos alunos copiam seus trabalhos, recorrentemente porque o que já está publicado é, na visão do estudante, considerado como algo de qualidade. Dessa maneira, é mais fácil e "garantido" acertar copiando um conteúdo da internet do que arriscando produzir um texto próprio, que pode ser insuficiente ou errado. Consoante Abranches (2016), esta visão parte de um viés pedagógico no qual o estudante recorrentemente é julgado como errado e insuficiente, colaborando para a disseminação de ações mecânicas e pouco colaborativas para 0 processo de ensino-aprendizagem, como a cópia.

Na legenda da publicação de Instagram, a dupla E e F não utilizou aspas para destacar a citação, nem indicou a fonte de pesquisa das imagens ou do texto copiado. Quando questionadas a este respeito, na entrevista, a dupla revelou que não havia necessidade de informar a fonte. Vejamos:

$\mathrm{P}$ : Os sites consultados não foram citados nas publicações. Vocês só pegaram do site e colaram na publicação. Vocês acham que na publicação de Instagram não é necessário mostrar a fonte, apresentar a fonte?

F: Eu acho que não.

E: É, depende também, né? 
F: É.

E: Porque tem certas coisas que tem o autor, ou alguma coisa do tipo, que pertence a alguém

P: Tipo uma frase

E: É. Ai tem que colocar os créditos, ne?

P: Mas por exemplo, assim, uma informação que tem num site, por exemplo, é... " $50 \%$ da população brasileira sofre de depressão". Aí você copia isso e cola na publicação. Não precisa dizer...

$F:$ Ah, eu acho que não.

$\mathrm{P}:$ A origem dos dados, nada?

E: Eu acho que não.

P: Por que não é de alguém, se tá num site...

F: Tá no site, tipo assim, só tá no site.

E: Só copia e cola.

$P:$ Não é pertencente àquele site. Tá na internet, é de todo mundo.

\section{E: É.}

F: É, eu acho.

Pelo excerto da entrevista, é possível perceber que, na visão das estudantes, apenas é necessário indicar a referência de um texto quando este é uma frase de algum autor, no sentido mais canônico da palavra. Nesses casos, a frase “pertence a alguém”, então é preciso expor. Em outras situações, como na apresentação de dados e informações contidas em um site, é possível copiar e utilizá-los sem indicar a origem. Ainda na entrevista, a pesquisadora questionou se uma informação online não pertence a ninguém, "é de todo mundo", e ambas alunas responderam afirmativamente. Xavier (2010) discute a "dessacralização do autor" que acontece na internet devido ao espaço que qualquer usuário, sem nenhum vínculo institucional ou aval técnico, tem para lançar materiais, com a liberdade de ser "autor". A partir da situação de cópia-colagem ocorrida nessa retextualização no smartphone, afirmamos ainda que, além da liberdade de publicação, a dessacralização do autor pode aparecer na perspectiva da perda da identidade autoral, haja vista que os textos, diversas vezes, são replicados sem referenciação.

O tema da cópia-colagem também apareceu na entrevista quando a pesquisadora perguntou às alunas sobre as diferenças que permeiam a retextualização no papel e no celular:

$P$ : Quais diferenças vocês perceberam entre produzir um texto no papel, ne, com caneta e papel, e um texto no celular?

E: A diferença?

P: É. As. Eu acho que tem várias.

E: Bastante.

F: a primeira diferença é que... 
P: O que você usa pra fazer um texto no celular?

E: Os dedos e o celular.

P: Tá. E pra fazer no papel?

E: Só a caneta e o papel.

$\mathrm{F}$ : Às vezes uma borracha e às vezes um lápis.

P: Então mudam os materiais...

F: É, e às vezes no celular, por exemplo, você já tem a opção de ter um corretor automático.

E: Já escreve e já corrige tudo.

$F$ : É, e escrevendo às vezes você não tem isso, às vezes você pode passar uma palavra errada sem perceber, e no celular sempre tem essa mania de você tá tipo corrigir automaticamente, sem você nem perceber.

E: Você pode copiar e colar de outra coisa também.

F: É.

P: Hum, copiar e colar, ne? Você já copia e cola.

$\mathrm{F}$ : Algum trecho interessante, ou alguma frase que você vai querer

E: Já no papel, não, você tem que escrever, escrever...

Tendo em vista as diferenças levantadas pelas alunas, é possível afirmar que, de acordo com $\mathrm{E}$ e $\mathrm{F}$, produzir um texto no papel diferencia-se de produzir um hipertexto no smartphone nos seguintes aspectos: (i) materiais utilizados (no suporte físico - papel, lápis, borracha e caneta; no suporte digital - os próprios dedos e o celular); (ii) a atuação do corretor ortográfico automático no celular; (iii) possibilidade de copiar e colar textos facilmente, sem a necessidade de "escrever e escrever", como no papel. Assim, a cópia-colagem mais uma vez foi considerada natural e espontânea pelas alunas, como uma possibilidade da produção hipertextual, sem implicações legais do plágio ou prejuízos para a aprendizagem. Durante o diálogo mantido pelas alunas na retextualização e na entrevista, elas não questionaram ou julgaram a atividade de cópia-colagem. Como afirma Abranches (2016, p. 168): "Esta proximidade entre disponibilidade e facilidade de obtenção do que se quer e a familiaridade com as tecnologias fazem com que tal prática seja rapidamente assimilada como algo possível e isento de maiores questionamentos".

Diante das discussões levantadas sobre a retextualização que originou a publicação de Instagram, a partir dos dados indiciários e processuais, temos que a tarefa de hipertextualização englobou não somente a produção verbal escrita da publicação (a legenda), mas também a pesquisa, a escolha e a montagem dos recursos semióticos, devido à estrutura do gênero em pauta. Diferentemente 
da carta, as alunas tinham habilidade com o gênero discursivo digital e não precisaram consultar materiais de apoio para compreender sua estrutura. Além disso, as dúvidas ortográficas que poderiam permear o processo, de acordo com as alunas, são sanadas com auxílio do corretor automático do celular. A independência leitora propiciada pelo hipertexto, como discutida por Xavier (2010), possibilitou às alunas a pesquisa e seleção dos próprios texto-base. Por fim, os recursos do smartphone, como buscar, copiar e colar, favoreceram a cópia-colagem que apareceu na publicação de Instagram, servindo de alerta aos docentes a respeito da necessidade de conscientizar os estudantes a respeito do plágio e das vantagens em elaborar os próprios textos e hipertextos.

\section{Considerações finais}

A inserção de gêneros discursivos digitais nas aulas de Língua Portuguesa não deve desencorajar o ensino dos gêneros da cultura impressa, mas considerar a cibercultura e valorizá-la como parte da sociedade, como orienta a BNCC (BRASIL, 2018). A exemplo das contribuições para o ensino-aprendizagem que o trabalho com o hipertexto apresenta, temos a compreensão, ampliada pela leitura sinestésica; a independência leitora, na qual o estudante elege os textos para sua aprendizagem; e a pro- dução textos multimodais, acionando diversas linguagens para construção de sentidos. Todavia, nossos dados demonstraram uma desvantagem relativa à cópia-colagem, que pode ser evitada com a conscientização dos estudantes a respeito do plágio e maior envolvimento dos estudantes com a atividade. Por meio das análises das tarefas de textualização e hipertextualização nos dois processos de retextualização aqui analisados, em papel (com a produção de uma carta) e no smartphone (com a produção de uma publicação de Instagram), foi possível perceber diferenças que permeiam esses processos, como os materiais utilizados para produção, as origens dos textos-base, recursos semióticos utilizados e dificuldades levantadas pelas alunas, o que justifica tratá-los distintamente dentro da Linguística.

\section{Retextualize on cell phone: implications of textualization and hypertextualization tasks}

\section{Abstract}

This article is about the retextualization that, according to Marcuschi (2010), is the process of building a text from another or other base-text(s). Considering the need of inserting digital genres of discourse in Portuguese Language classes, as BNCC (BRASIL, 2018) proposes, two retextualizations were compared, one produced on paper and the other on the cell phone, having the goal of analyzing the textua- 
lization and the hypertextualization, that are considered retextualization tasks. Therefore, procedural data were analyzed from a pair of High School students, that produced, jointly, a letter and an Instagram post. This paper is based on authors like Bakhtin (2011), Costa Val (2004), Dell'Isola (2007), Koch and Elias (2008) and Xavier (2010). By the analysis performed, it was noticed that textualization and hypertextualization differ due to the possibilities covered by the hypertext, of multisemiotic character, that allows synesthetic reading, reader independence, multimodal production, but, as disadvantage, the copy-collage.

Keywords: Digital writing; Hypertext; Instagram; Joint writing; Retextualization.

\section{Referências}

ABRANCHES, S. P. O que fazer quando eu recebo um trabalho CRTL+C, CRTL+V? Autoria, pirataria e plágio na era digital: desafios para a prática docente. In: XAVIER, A. C. [et al.]. Hipertexto e cibercultura: links com literatura, publicidade, plágio e redes sociais. São Paulo: Respel, 2016. p. 165-185.

ANTUNES, I. C. Lutar com palavras: Coesão e coerência. São Paulo: Parábola Editorial, 2005.

BAKHTIN, M. Estética da Criação Verbal. Tradução de Paulo Bezerra. 6. ed. São Paulo: Editora Martins Fontes, 2011.

BEAUGRANDE, R. A.; DRESSLER, W. U. Introduction to Text Linguistics. London, Longman, 1981.

BRASIL. Base Nacional Comum Curricular. Brasília, MEC/CONSED/UNDIME, 2018. Disponível em: <http://basenacionalcomum. mec.gov.br/images/BNCC_EI_EF_110518_ versaofinal_site.pdf> Acesso em: 12 jul. 2020.
COSTA VAL, M. G. Texto, textualidade e textualização.IN: CECCANTINI, J.L. Tápias; PEREIRA, Rony F.; ZANCHETTA JR., Juvenal. Pedagogia Cidadã: cadernos de formação: Língua Portuguesa. v. 1. São Paulo: UNESP, Pró-Reitoria de Graduação, 2004. p. 143 113-128. Disponível em: <https:// pt.scribd.com/doc/143600620/COSTA-VAL-Maria-da-Gra\%C4\%B1a-Texto-textualidade-textualiza\%C4\%B1\%C4\%B10>. Acesso em: 06 abr. 2020.

DELL'ISOLA, R. L. P. Retextualização de gêneros escritos. Rio de Janeiro: Lucerna, 2007.

DOLZ, J.; NOVERRAZ, M.; SCHNEUWLY, B. Sequências didáticas para o oral e a escrita: apresentação de um procedimento. In: SCHNEUWLY, B.; DOLZ, J. et al. Gêneros orais e escritos na escola. Tradução de Roxane Rojo e Glaís Sales. 3. ed. Campinas: Mercado das Letras, 2011, p. 81-108.

KOCH, I. V.; ELIAS, V. M. Ler e compreender: os sentidos do texto. 2. ed. São Paulo: Contexto, 2008.

LÉVY, P. Cibercultura. Rio de Janeiro: Editora $34,1999$.

MARCUSCHI, L. A. Da fala para a escrita: atividades de retextualização. 10. ed. São Paulo: Cortez, 2010.

Produção textual, análise de gêneros e compreensão. São Paulo: Parábola Editorial, 2008.

MATENCIO, M. L. M. Atividades de (re) textualização em práticas acadêmicas: um estudo do resumo. In: Scripta, Belo Horizonte, v.6, n. 11, p.109-122, 2002.

NELSON, T. H. Literary machines. Mindfiel Press, 1990.

PEREIRA, M. H. M. Tinha um gênero no meio do caminho. A relevância do gênero para a constituição do estilo em textos de escolares. Tese (Doutorado em Linguística Aplicada). Instituto de Estudos da Linguagem - Universidade Estadual de Campinas, São Paulo, 2005. 
G1. Setembro amarelo: como conversar com alguém que está pensando em cometer suicídio. 09 set. 2019. Disponível em: <https:/g1.globo.com/ciencia-e-saude/ noticia/2019/09/09/setembro-amarelo-como-conversar-com-alguem-que-esta-pensando-em-cometer-suicidio.ghtml>. Acesso em: 28 maio 2020.

ROJO, R. H. R; BARBOSA, J. P. Hipermodernidade, multiletramentos e gêneros discursivos. São Paulo: Parábola Editorial, 2015.

XAVIER, A. C. Leitura, texto e hipertexto. In: Hipertexto e gêneros digitais: novas formas de construção de sentido. MARCUSCHI, L. A.; XAVIER, A. C. (Orgs). 3. ed. São Paulo: Cortez, 2010. p. 207-220. 